\title{
Rapid respiratory panel test for non-COVID- 19 pathogen examinations among frontline medical personnel in Taiwan
}

\author{
Yu-Chih Chen ${ }^{1}$, Huei-Wen Lai ${ }^{2}$, I-Lun Hou², Pei-You Hsieh', Po-Yu Wang ${ }^{3}$, Ting-Yuan Ni ${ }^{1}$, Chu-Chung Chou ${ }^{1,4,5}$ and \\ Yan-Ren $\operatorname{Lin}^{1,4,5^{*}}$ (D)
}

To the Editor:

Handling over 100 million COVID-19 cases, frontline medical personnel are threatened due to the high risk of cross-infection. Several studies have recommended that medical personnel with suspicious symptoms (including fever, cough, diarrhea, muscle pain, and loss of smell) clearly receive SARS-CoV-2 testing and at least 14 days of quarantine (close contact with COVID-19 patients without appropriate infection prevention) [1]. Lacking personnel would slow down the hospital operation and further impact patient safety. Notably, we agree that COVID-19 should be excluded first. However, early identification of "non-COVID-19" pathogens would also be beneficial for adjusting the length of quarantine and the policy of workforce resupply. For example, medical personnel with rhinovirus infection might not need 14day quarantine. Unfortunately, information regarding non-COVID-19 pathogens (including coinfections) among frontline medical personnel is not well known, and we aim to present our experience in Taiwan.

From 1 March to 30 June 2020, a total of 1272 patients were reported to the Taiwan CDC for testing COVID-19 (SARS-CoV-2) in our hospital. Among them, 115 (9\%) were frontline medical personnel (handling or facing patients). In addition, 105 of them (91.3\%) received rapid respiratory panel test (BIOFIRE $^{\bullet}$ FILMARRAY $^{\circ}$ Respiratory Panels) in the emergency department (ED) (Table 1). All of them were negative for COVID-19. However, 26 $(24.7 \%)$ of them tested positive for non-COVID

\footnotetext{
* Correspondence: h6213.lac@gmail.com

${ }^{1}$ Department of Emergency and Critical Care Medicine, Changhua Christian Hospital, Changhua City, Taiwan

${ }^{4}$ School of Medicine, Kaohsiung Medical University, Kaohsiung, Taiwan

Full list of author information is available at the end of the article
}

pathogens, including 18 (17.1\%) who were positive for human rhinovirus/enterovirus RNA, 2 (1.9\%) who were positive for coronavirus OC43 RNA, and 2 (1.9\%) who were positive for coronavirus NL63 RNA (Table 2). Three (2.9\%) patients had coinfections ( 2 or $>2$ categories of virus). The first was coinfected with coronavirus OC43 RNA and human rhinovirus/enterovirus RNA, the second was coinfected with adenovirus DNA and human rhinovirus/enterovirus RNA, and the last was coinfected with parainfluenza virus 4 RNA and respiratory syncytial virus RNA.

Among the medical personnel (with suspected symptoms), our results demonstrated that $24.7 \%$ tested positive for non-COVID pathogens. Rhinoviruses and enteroviruses were the leading non-COVID-19 pathogens during the pandemic period. When facing workforce insufficiency, long-term quarantine for medical personnel might not be necessary when their COVID-19 and non-COVID-19 pathogens are both confirmed early.

Table 1 Demographics of patients who received non-COVID-19 pathogen examinations

Medical personnel $(n=105)$

Sex

Male $19(18.1 \%)$

Female $86(81.9 \%)$

Age (years)

$<31 \quad 43(41.0 \%)$

$31-40 \quad 40(38.1 \%)$

$41-50 \quad 18(17.1 \%)$

$51-60 \quad 4(3.8 \%)$ 
Table 2 Categories of pathogens of 105 patients who received non-COVID-19 pathogen examinations

\begin{tabular}{ll}
\hline Detected virus & No. (\%) \\
\hline Rhinovirus/enterovirus RNA & $18(17.1 \%)$ \\
Coronavirus OC43 RNA & $2(1.9 \%)$ \\
Coronavirus NL63 RNA & $2(1.9 \%)$ \\
Adenovirus DNA & $2(1.9 \%)$ \\
Parainfluenza virus 4 & $2(1.9 \%)$ \\
Respiratory syncytial virus RNA & $1(1.0 \%)$ \\
Coronavirus HKU1 RNA & $1(1.0 \%)$ \\
\hline
\end{tabular}

In one testing model, the chance of post-quarantine transmission might obviously decrease after 7 days of quarantine [2]. A rapid respiratory panel test in the ED might be effective for early detection. Finally, we recommend that the quarantine period should be at least 7 days for (suspected symptoms) medical personnel who are negative for all pathogens (including COVID-19 and FILMARRAY Respiratory Panels).

\section{Acknowledgements}

None.

\section{Authors' contributions}

Y-CC and Y-RL conceptualized and designed the study. Y-CC and H-WL helped draft the manuscript. I-LH and P-YH collected the data and prepared the table. P-YW and T-YN reviewed and provided conceptual advice for the manuscript. Y-RL and C-CC revised the manuscript. The author(s) read and approved the final manuscript.

\section{Funding}

None.

Availability of data and materials

Not applicable.

\section{Ethics approval and consent to participate}

Institutional Review Board of Changhua Christian Hospital permission number 200409.

\section{Consent for publication}

Not applicable.

\section{Competing interests}

The authors declare that they have no competing interests.

\section{Author details}

${ }^{1}$ Department of Emergency and Critical Care Medicine, Changhua Christian Hospital, Changhua City, Taiwan. ${ }^{2}$ Center of Infection Prevention and Control, Changhua Christian Hospital, Changhua City, Taiwan. ${ }^{3}$ Department of Pediatric Emergency, Changhua Christian Children's Hospital, Changhua City, Taiwan. ${ }^{4}$ School of Medicine, Kaohsiung Medical University, Kaohsiung, Taiwan. ${ }^{5}$ School of Medicine, Chung Shan Medical University, Taichung, Taiwan.

Received: 10 November 2020 Accepted: 3 February 2021

Published online: 13 February 2021

\section{References}

1. Lauer SA, Grantz KH, Bi Q, et al. The incubation period of coronavirus disease 2019 (COVID-19) from publicly reported confirmed cases: estimation and application. Ann Intern Med. 2020;172(9):577-82. https://doi.org/10.7326/ M20-0504
2. Wells CR, Townsend JP, Pandey A, et al. Nat Commun. 2021;12(1):356. https://doi.org/10.1038/s41467-020-20742-8.

\section{Publisher's Note}

Springer Nature remains neutral with regard to jurisdictional claims in published maps and institutional affiliations.
Ready to submit your research? Choose BMC and benefit from:

- fast, convenient online submission

- thorough peer review by experienced researchers in your field

- rapid publication on acceptance

- support for research data, including large and complex data types

- gold Open Access which fosters wider collaboration and increased citations

- maximum visibility for your research: over $100 \mathrm{M}$ website views per year

At BMC, research is always in progress.

Learn more biomedcentral.com/submissions 